\title{
O VALOR INDENIZATÓRIO EM DESAPROPRIAÇÕES DE ÁREAS DE PRESERVAÇÃO PERMANENTE EM ZONA URBANA
}

\author{
Romeu Thomé \\ Pós-Doutor em Direito Ambiental pela Université Laval, \\ Canadá. Doutor em Direito pela PUCMG. Mestre em \\ Direito pela UFMG. Professor permanente do Mestrado \\ em Direito Ambiental e Desenvolvimento Sustentável da \\ Escola Superior Dom Helder Câmara. \\ romeuprof@hotmail.com
}

RESUMO: O trabalho analisa a definição de parâmetros para a fixação do quantum indenizatório na desapropriação de Área de Preservação Permanente (APP) de imóvel urbano. A potencialidade econômica é fator chave para a mensuração dos valores indenizatórios nos casos de desapropriação de imóveis situados em áreas urbanas ou rurais. Não é justa a adoção de critérios idênticos para definir a indenização de áreas com potencialidades distintas. Foram utilizados, além do método jurídico-comparativo, o jurídico-propositivo, a fim de sugerir a necessária utilização de critérios diversos para a fixação do valor da indenização nos casos de desapropriação de APP em imóveis localizados em áreas urbanas ou em áreas rurais. A adoção, pela Administração Pública, de critérios de cálculos específicos para os imóveis rurais na desapropriação de APP urbana afigura-se flagrantemente ilegal e passível, inclusive, de impugnação judicial.

PALAVRAS-CHAVE: Área de preservação permanente. Desapropriação. Indenização. Zonas urbanas.

The expropriation of permanent preservation area in urban area and the economic compensation

\begin{abstract}
This paper has as scope to analyze the definition of parameters for the fixation of the economic compensation in the expropriation of Permanent Preservation Area (APP) of urban property. The economic potential of the property is essential for the analysis of indemnity values in cases of expropriation. It is not appropriate to adopt identical parameters to set the compensation of areas with different potentialities. The legal-comparative and legal-purpose methods were used, with the purpose of suggesting the use of different parameters to determine the value of the economic compensation in cases of expropriation of APP, based on the analysis of the properties characteristics. It is concluded that the adoption by the Public Administration of criteria adopted in the expropriation of rural properties for the expropriation of APP in urban area is illegal.
\end{abstract}

KEYWORDS: Permanent preservation area. Expropriation. Economic compensation. Urban area.

\section{INTRODUÇÃO}

A propriedade é assegurada pela Constituição Federal de 1988 (CF/1988) e se afigura como o núcleo do direito das coisas. $\mathrm{O}$ direito de propriedade sofre, no entanto, inúmeras limi- 
tações no direito positivo contemporâneo, justificadas pela supremacia do interesse público. O interesse privado, individual, não pode se sobrepor aos interesses maiores da coletividade.

A intervenção estatal sobre a propriedade privada revela um poder jurídico do Estado, calcado em sua própria soberania. Desse modo, a intervenção do Estado decorre de seu próprio poder de império (ius imperii), a ele devendo sujeição os particulares.

No caso de intervenção na propriedade, há uma atuação vertical do poder público, que estabelece imposições que de alguma forma limitam o uso da propriedade.

Há inúmeras formas de intervenção do Estado na propriedade privada, que variam de acordo com os fins colimados pela Administração Pública. Elas são didaticamente classificadas em: a) intervenção restritiva e; b) intervenção supressiva.

$\mathrm{Na}$ intervenção restritiva, o poder público retira algumas das faculdades relativas ao domínio, embora mantenha a propriedade em favor do dono. Renomados doutrinadores do Direito Administrativo pátrio, como Di Pietro (2001) e Marinela (2010), apontam como modalidades de intervenção restritiva a servidão administrativa, a requisição, a ocupação temporária, as limitações administrativas e o tombamento.

Já a intervenção supressiva gera a transferência coercitiva da propriedade de seu dono para o Estado, em virtude de utilidade pública ou o interesse social, previstos em lei. Como se vê, essa drástica intervenção estatal acarreta a perda da propriedade pelo particular. Para a melhor doutrina administrativista, capitaneada por Carvalho Filho (2013), a única modalidade desse tipo de intervenção é a desapropriação.

No presente trabalho pretende-se analisar os critérios utilizados para o cálculo do quantum indenizatório nos casos de desapropriação de área de preservação permanente (APP) em imóvel urbano, pressupondo haver prévia justificativa de sua utilidade pública.

Nos termos da Lei Federal 12.651/2012, popularmente denominada Código Florestal (CFlo/2012), APP é uma espécie de área especialmente protegida, com importantes funções ambientais, tais como as de preservar os recursos hídricos, a paisagem, a estabilidade geológica e a biodiversidade, além de facilitar o fluxo gênico de fauna e flora, proteger o solo e, ainda, assegurar o bem-estar das populações humanas.

As APPs podem ser instituídas em função de sua localização ou em função de sua destinação.

No que concerne às APPs instituídas em função de sua localização, convém sublinhar que se referem a vegetação situada em áreas fundamentais para a prevenção contra erosão do solo, assoreamento, proteção do curso dos rios e das nascentes como, por exemplo, as matas ciliares. As singularidades desses espaços motivaram o legislador a instituir proteção ambiental por intermédio de lei (ex vi legis). Neste passo, o próprio CFlo/2012, no artigo $4^{\circ}$, se encarregou de tornar essas áreas ambientalmente protegidas, tais como "as áreas no entorno das nascentes e dos olhos d'água perenes, no raio mínimo de 50 (cinquenta) metros”, ou as "restingas, como fixadoras de dunas ou estabilizadoras de mangues". (BRASIL, 2012).

Além das APPs instituídas em razão de sua localização, podem ainda ser criadas APPs em função de sua destinação (artigo $6^{\circ}$ ). Nesse caso, deverão ser declaradas de interesse social por ato do Chefe do Poder Executivo as áreas cobertas com florestas ou outras formas de vegetação destinadas a finalidades diversas, tais como conter a erosão do solo ou proteger sítios de excepcional beleza ou de valor científico. (BRASIL, 2012). 
Importa ressaltar ainda que, nas hipóteses do artigo $6^{\circ}$, determinada área pode ser declarada como de preservação permanente através de decreto exarado tanto pelo chefe do Poder Executivo Federal, quanto por Governadores e Prefeitos.

Impõe-se sublinhar que, como a própria expressão denota, áreas de preservação permanente indicam áreas ambientalmente relevantes e, como tal, devem ter sua vegetação preservada.

Toda propriedade rural ou urbana, seja ela de domínio público ou privado, deverá manter preservadas as APPs, respeitando o preceito constitucional da função socioambiental da propriedade. A vegetação das APPs, preservada, contribui para manter o equilíbrio ambiental, direito de todos, nos termos do artigo 225, caput, da CF/1988. Da leitura deste dispositivo constitucional desata a compreensão de que a vegetação localizada em APP deve ser mantida pelo proprietário da área, possuidor ou ocupante, seja pessoa física ou jurídica.

$\mathrm{O}$ artigo $2^{\circ}$ do CFlo/2012 indica que a instituição de Áreas de Preservação Permanente tem natureza de limitação à propriedade. Trata-se de uma limitação restritiva com fundamento no princípio constitucional da função socioambiental da propriedade. Limitação restritiva, pois nos casos de APP em propriedades privadas não há a desapropriação (limitação supressiva) do bem, mas apenas a restrição da utilização da propriedade privada, calcada na sua função socioambiental. (BRASIL, 2012-b).

Por oportuno, convém registrar que não cabe, portanto, de forma genérica, indenização ao proprietário que alegue prejuízo econômico em decorrência da impossibilidade de exploração direta da(s) área(s) considerada(s) como APPs em sua propriedade. Tais limitações, gerais e abstratas, são instituídas por lei e têm como objetivo a proteção de interesses transindividuais, devendo ser observadas por todas as propriedades que apresentem as características descritas pela Lei Federal 12.651/2012. (THOMÉ, 2018).

No presente trabalho pretende-se analisar se, para o cálculo indenizatório pela aquisição de área, na desapropriação, deverão ser levadas em consideração as APPs existentes no imóvel e, em caso afirmativo, se o cálculo da indenização das APPs em áreas urbanas deverá utilizar critérios iguais ou distintos daqueles utilizados para o cálculo das APPs rurais.

Utilizou-se o método jurídico-comparativo para a identificação das características e funções das APPs em áreas urbanas e rurais, além do método jurídico-propositivo, a fim de sugerir a necessária utilização de critérios diversos para a fixação do valor da indenização nos casos de desapropriação de APP em imóveis localizados em áreas urbanas.

A escassez bibliográfica e o reduzido enfrentamento pelo Poder Judiciário de ações de desapropriação urbana com áreas de preservação permanente e, por conseguinte, de critérios específicos para o cálculo do quantum indenizatório, além da necessidade de se buscar a aproximação entre os institutos de direito ambiental e de direito administrativo a partir de uma análise interdisciplinar, justificam a escolha do tema proposto.

\section{INDENIZABILIDADE NOS CASOS DE DESAPROPRIAÇÃO DE APP}

É cediço que a mera existência de APP em propriedade privada não tem o condão de assegurar ao seu proprietário o direito de receber indenização. Sob outra perspectiva, não se pode olvidar que cabe indenização ao proprietário de imóvel, rural ou urbano, que tenha sua propriedade expropriada pelo poder público. 
As intervenções estatais por meio de limitações à propriedade têm fundamento constitucional e estão calcadas no postulado da supremacia do interesse público e no princípio da função social da propriedade. Observa Araújo (2017, p. 262) "que o direito de propriedade continua a ser um direito fundamental, porém vinculado ao dever de cumprir a função social e a função ambiental". O artigo $5^{\circ}$, inciso XXII, da CF/1988, condiciona o direito de propriedade ao atendimento da função social. Observam Matias e Mendes (2016, p. 16) que

\begin{abstract}
a evolução histórica que a ideia de função social experimentou, passando, em verdade, de mera justificação da proteção jurídica de certos institutos, sem positivação, quem dirá aplicabilidade, no contexto do Estado Liberal, a norma jurídica que visava a submissão da propriedade - aqui inclusa a empresa, como irá se expor a seguir - a interesses da coletividade, mas ainda sem aplicabilidade imediata, no contexto do Estado Social, até o paradigma atual de reconhecimento da eficácia jurídica do princípio da função social, sendo dotada de aplicabilidade imediata.
\end{abstract}

Advirta-se, por oportuno, que a utilidade pública se caracteriza quando a transferência do bem se apresenta conveniente para a Administração Pública. Já o interesse social, diferentemente, está presente nas hipóteses em que mais se realça a função social da propriedade.

$\mathrm{O}$ inciso XXIV do art. $5^{\circ}$ da $\mathrm{CF} / 1988$, considerado o dispositivo fundamental para as desapropriações, enuncia que "a lei estabelecerá o procedimento para desapropriação por necessidade ou utilidade pública, ou por interesse social, mediante justa e prévia indenização em dinheiro, ressalvados os casos previstos nesta Constituição.” (BRASIL, 1988).

Cumpre rememorar que a competência para declarar a utilidade pública de imóvel para fins urbanísticos é do Município, nos termos do artigo 30, incisos I e VIII e art. 182, §3ºmbos da CF.

A indenização ofertada deve corresponder ao real valor do bem expropriado, ou seja, essa especial modalidade de contraprestação deve ser suficiente para recompor o patrimônio do particular.

O valor da indenização a ser paga pelo ente expropriante ao particular, não raras vezes, enseja o ajuizamento de ação para sua fixação judicial, pois nem sempre o procedimento administrativo logra a obtenção de acordo entre as partes sobre o preço do bem. Cumpre observar, por oportuno, que o mérito da contestação somente poderá discutir o quantum indenizatório.

Importa, nesse ponto, analisar especificamente a indenização devida em razão da desapropriação de imóveis urbanos detentores de Áreas de Preservação Permanente-APP.

Poder-se-ia indagar, inicialmente, qual seria o interesse do poder público em desapropriar a APP de determinado imóvel, tendo em vista o seu caráter de proteção estabelecido pelas normas ambientais. O próprio CFlo/2012 apresenta-nos a resposta: a redação do artigo $8^{\circ}$ prevê a possibilidade de intervenção ou supressão de vegetação em APP, mediante autorização do órgão ambiental competente, nos casos de utilidade pública.

Desse modo, a vegetação em APP poderá ser suprimida, por exemplo, para atividades de proteção sanitária ou para obras necessárias à defesa civil, assim como para a realização "de obras de infraestrutura destinadas às concessões e aos serviços públicos de transporte, sistema viário, inclusive aquele necessário aos parcelamentos de solo urbano aprovados pelos Municípios, saneamento, gestão de resíduos, energia, telecomunicações e radiodifusão". (artigo 8', caput, c/c artigo 30, inciso VIII, "a", "b" e "c" da Lei 12.651/2012). (BRASIL, 2012).

Como se vê, em determinadas situações específicas, delimitadas em cada caso concreto, deverá o poder público intervir em APP localizada em propriedade privada para a realização de 
atividades de utilidade pública. Tais intervenções podem ser supressivas e, nesses casos, materializam-se por meio do instituto da desapropriação da área, com o prévio pagamento da devida indenização ao proprietário do imóvel.

Resta claro que, nos casos de desapropriação integral, por utilidade pública, de propriedades detentoras de áreas de preservação permanente ou de desapropriação parcial que atinja apenas as APPs, tais áreas ambientalmente protegidas devem ser consideradas no cômputo final do valor indenizatório da desapropriação.

Para se exonerar da responsabilidade de indenizar os proprietários pelo espaço da APP presente em propriedade privada, o ente expropriante usualmente sustenta argumentos nada convincentes, como o de que as áreas ambientalmente protegidas localizadas em propriedades privadas, em decorrência de suas características preservacionistas, não seriam indenizáveis pelo poder público, ou de que a proibição do uso e gozo da área ou de sua potencialidade pelo proprietário resultaria no esvaziamento do seu valor econômico para fins de indenização nos casos de desapropriação.

Não se pode olvidar que

as APPs se configuram como limitações restritivas à propriedade, afetando o caráter absoluto da mesma, o que não as excluem do domínio do proprietário. Assim, o valor da indenização nos casos de desapropriação deverá abarcar toda a extensão da propriedade, inclusive as Áreas de Preservação Permanente. (THOMÉ, 2018, p. $323)$.

O fato de se caracterizarem como áreas de proteção ambiental não esvazia o valor econômico de uma APP, devendo ser devidamente indenizadas pelo poder público. A jurisprudência também tem se posicionado neste sentido. Vejamos.

DESAPROPRIAÇÃO DIRETA. MATAS SUJEITAS À PRESERVAÇÃO PERMANENTE. VEGETAÇÃO DE COBERTURA. INDENIZAÇÃO DEVIDA. RECURSO DESPROVIDO.

A existência de cobertura vegetal sujeita à limitação legal quanto à exploração não elimina o valor econômico das matas preservadas, nem afeta negativamente o patrimônio do expropriado. Não é admissível considerar essa vegetação como elemento neutro na apuração do valor devido pelo expropriante, máxime quando o uso do subsolo implicará no desmatamento da área com o aproveitamento econômico da extração da madeira. (PARANÁ, 2004).

ADMINISTRATIVO. DESAPROPRIAÇÃO INDIRETA.PRESCRIÇÃO. MATAS DE PRESERVAÇÃO PERMANENTE. INDENIZABILIDADE. LAUDO PERICIAL. SUM. 7/STJ. JUROS COMPENSATORIOS.CUMULAÇÃO DOS JUROS MORATORIOS COMO OSCOMPENSATORIOS. APLICAÇÃ̃O, NA ESPÉCIE, DASSUMULAS 12, 69, 70, 98, 102 E 114/STJ.

[...]. Conforme já decidiu esta corte, as matas que recobrem a área expropriada representam um valor econômico, portanto, as limitações administrativas quando superadas pela ocupação permanente, vedando o uso, gozo e livre disposição da propriedade, impõe-se a obrigação indenizatória justa, espancando mascarado confisco. A discussão quanto à indenização esbarra na Súmula 7/STJ, uma vez que é impossível o seu reexame pela via eleita do especial. "Na desapropriação direta, os juros compensatórios são devidos desde a antecipada imissão na posse e, na desapropriação indireta, a partir da efetiva ocupação do imóvel". - Sum. 69/STJ. Da mesma forma: "os juros compensatórios, na desapropriação indireta, incidem a partir da ocupação, calculados sobre o valor da indenização, corrigido monetariamente." Sum. 114/STJ. "A incidência dos juros moratórios sobre os compensatórios, nas ações expropriatórias, não constitui anatocismo vedados em lei." Sum.12 e Sum. 102/STJ. Recurso especial a que se nega provimento. (BRASIL, 1997).

RECURSO EXTRAORDINARIO - ESTACÃO ECOLÓGICA - RESERVA FLORESTAL NA SERRA DO MAR - PATRIMÔNIO NACIONAL (CF, ART. 225, 
PAR.4.) - LIMITAÇÃO ADMINISTRATIVA QUE AFETA O CONTEÚDO ECONÔMICO DO DIREITO DE PROPRIEDADE - DIREITO DO PROPRIETÁRIO A INDENIZAÇÃO - DEVER ESTATAL DE RESSARCIR OS PREJUÍZOS DE ORDEM PATRIMONIAL SOFRIDO SPELO PARTICULAR - RE NÃO CONHECIDO.

Incumbe ao Poder Publico o dever constitucional de proteger a flora e de adotar as necessárias medidas que visem a coibir práticas lesivas ao equilíbrio ambiental. Esse encargo, contudo, não exonera o Estado da obrigação de indenizar os proprietários cujos imóveis venham a ser afetados, em sua potencialidade econômica, pelas limitações impostas pela Administração Pública. A proteção jurídica dispensada as coberturas vegetais que revestem as propriedades imobiliárias não impede que o dominus venha a promover, dentro dos limites autorizados pelo Código Florestal, o adequado e racional aproveitamento econômico das arvores nelas existentes. A jurisprudência do Supremo Tribunal Federal e dos Tribunais em geral, tendo presente a garantia constitucional que protege o direito de propriedade, firmou-se no sentido de proclamar a plena indenizabilidade das matas e revestimentos florestais que recobrem áreas dominiais privadas objeto de apossamento estatal ou sujeitas a restrições administrativas impostas pelo Poder Publico. Precedentes. A circunstância de o Estado dispor de competência para criar reservas florestais não lhe confere, só por si - considerando-se os princípios que tutelam, em nosso sistema normativo, o direito de propriedade -, a prerrogativa de subtrair-se ao pagamento de indenização compensatória ao particular, quando a atividade pública, decorrente do exercício de atribuições em tema de direito florestal, impedir ou afetar a válida exploração econômica do imóvel por seu proprietário. - A norma inscrita no art. 225, par. 4., da Constituição deve ser interpretada de modo harmonioso com o sistema jurídico consagrado pelo ordenamento fundamental, notadamente com a cláusula que, proclamada pelo art. 5., XXII, da Carta Política, garante e assegura o direito de propriedade em todas as suas projeções, inclusive aquela concernente a compensação financeira devida pelo Poder Público ao proprietário atingido por atos imputáveis a atividade estatal. O preceito consubstanciado no art. 225, par. 4., da Carta da República, além de não haver convertido em bens públicos os imóveis particulares abrangidos pelas florestas e pelas matas nele referidas (Mata Atlântica, Serra do Mar, Floresta Amazônica brasileira), também não impede a utilização, pelos próprios particulares, dos recursos naturais existentes naquelas áreas que estejam sujeitas ao domínio privado, desde que observadas as prescrições legais e respeitadas as condições necessárias a preservação ambiental. A ordem constitucional dispensa tutela efetiva ao direito de propriedade (CF/88, art. 5., XXII). Essa proteção outorgada pela Lei Fundamental da República estende-se, na abrangência normativa de sua incidência tutelar, ao reconhecimento, em favor do dominus, da garantia de compensação financeira, sempre que o Estado, mediante atividade que lhe seja juridicamente imputável, atingir o direito de propriedade em seu conteúdo econômico, ainda que o imóvel particular afetado pela ação do Poder Público esteja localizado em qualquer das áreas referidas no art. 225, par. 4., da Constituição. - Direito ao meio ambiente ecologicamente equilibrado: a consagração constitucional de um típico direito de terceira geração (CF, art.225, caput). (BRASIL, 1995).

Não restam dúvidas de que o imóvel urbano integrado por APP ostenta um valor superior a outros imóveis urbanos que não contam com essas especiais áreas ambientalmente protegidas, razão pela qual se impõe a respectiva indenização na hipótese de ocorrência de desapropriação.

\section{A INDENIZAÇÃO DE APP EM TERRENOS URBANOS E A DETERMINAÇÃO DE SEU VALOR}

Importante salientar, de pronto, que por disposição constitucional a indenização, nos casos de desapropriação por utilidade pública, deve ser justa, prévia e em dinheiro (artigo $5^{\circ}$, inciso XXIV, CF/1988). 
Para que seja justa, a indenização deve abarcar, além do valor atual do bem expropriado, também os danos emergentes e os lucros cessantes decorrentes da perda da propriedade, os juros moratórios e compensatórios, a atualização monetária, as despesas judiciais e os honorários advocatícios, quando for o caso.

Ensina Di Pietro (2001) que “a indenização é exigência que se impõe como forma de buscar o equilíbrio entre o interesse público e o privado; o particular perde a propriedade e, como compensação, recebe o valor correspondente ao dinheiro."

Para a definição do valor justo nos casos de desapropriação, uma série de critérios técnicos é utilizada pelos peritos responsáveis pelo cálculo. É cediço que os critérios usados nos casos de desapropriação de imóvel rural são distintos daqueles utilizados na desapropriação de imóvel urbano, em decorrência das características intrínsecas a cada um deles e, sobretudo, das formas de utilização e exploração desses imóveis.

Em determinadas situações específicas, o poder público utiliza, equivocada e indevidamente, critérios próprios para o cálculo do valor indenizatório de imóveis rurais em desapropriações de imóveis urbanos. Essa indistinta adoção de critérios tem o condão de esvaziar o valor do imóvel urbano desapropriado, acarretando prejuízos significativos ao particular.

Tal descompasso talvez se dê em virtude da inerente proximidade entre os institutos de direito ambiental e de direito urbanístico. Para Rúsvel Beltrame (2008), a aproximação entre essas duas disciplinas exige uma leitura harmônica do artigo 182, que trata da política urbana, e do artigo 225, que dispõe sobre a proteção do meio ambiente, ambos da CF/1988. Observa que "o regime jurídico do uso do solo não pode desconsiderar a proteção ambiental. Do mesmo modo, a proteção das áreas de preservação não pode desconsiderar as necessidades vitais dos habitantes das cidades (circulação, habitação, trabalho e lazer)."

Entretanto, a conexão e a afinidade entre as referidas disciplinas não podem se transmutar em confusão e aplicação incorreta de seus instrumentos. Nesse ponto, convém rememorar a inegável autonomia científica do direito ambiental e do direito urbanístico, ambos com seus institutos e objetivos bem delineados.

Assim como parte dos instrumentos de direito urbanístico são inaplicáveis às áreas rurais e às atividades desenvolvidas no campo, os institutos de direito ambiental a serem aplicáveis às áreas urbanas devem ser interpretados a partir da perspectiva do direito urbanístico e das características peculiares às cidades.

Interessa-nos analisar, especificamente, a função da APP em dois contextos distintos: quando localizada em área rural e quando situada em zona urbana.

A APP, espécie de espaço ambientalmente protegido, revela o intuito do legislador de resguardar, preferencialmente, o meio ambiente natural, em face do qual a intervenção humana apresenta-se apenas como aspecto incidental (ANTUNES, 2012). Nesse sentido, resta clara no artigo $3^{\circ}$, II do CFlo/2012, a função da APP localizada em zonas rurais: "função ambiental de preservar os recursos hídricos, a paisagem, a estabilidade geológica e a biodiversidade, facilitar o fluxo gênico de fauna e flora e proteger o solo". (BRASIL, 2012).

Já em zonas urbanas, a função da APP deve ser analisada de maneira sistêmica, levando-se em consideração os instrumentos de direito urbanístico e as normas específicas que disciplinam as atividades urbanas, como o plano diretor e a lei de uso e ocupação do solo. O regramento genérico do CFlo/2012, ao apontar a necessidade de proteção da APP em área urbana, não pode excluir a incidência das determinações específicas previstas nas normas urbanísti- 
cas. Nesses casos, as normas ambientais e urbanísticas devem ser interpretadas em conjunto, sob o pano de fundo da cidade e de suas peculiaridades.

O Código Florestal vigente, tal qual, nesse ponto, seu antecessor, expressamente prevê a possibilidade de instituição de APP em áreas urbanas, nos termos expressamente enunciados em seu artigo $4^{\circ}$. No entanto, nada obstante a literalidade da legislação de regência, há julgados que negam a aplicabilidade da APP em áreas urbanas. Vejamos.

\title{
EMBARGOS INFRINGENTES. AÇÃO CIVIL PÚBLICA. ANULAÇÃO DE LI- CENÇAS AMBIENTAIS. LEGISLAÇÃO FLORESTAL. FLORESTA URBANA, INEXISTÊNCIA DE ÁREA DE PREŞERVAÇÃO PERMANENTE.
}

\begin{abstract}
A embargada agiu dentro da legalidade, conforme orientações locais de proteção ambiental, não se tratando de área de preservação permanente, tendo em vista ser inaplicável ao caso o Código Florestal, que assim define as áreas 'de 30 (trinta) metros para os cursos d'água de menos de 10 (dez) metros de largura' (art. $2^{\circ}$, a, 1, da Lei 4.771/1965), uma vez que se trata de área urbana, cujas peculiaridades devem ser levadas em consideração ao se aplicar a legislação florestal”. (BRASIL, 2008).
\end{abstract}

No mesmo sentido decisão do Tribunal de Justiça de Santa Catarina:

$\mathrm{O}$ art. $2^{\circ}$ da Lei 4.771/65 - Código Florestal e art. $4^{\circ}$, inc. III, da Lei 6.766, de 19/ 12/79 - Parcelamento do Solo, não se contradizendo, mas convivendo, ocupam-se de situações de fato diferentes: o Código Florestal é aplicável à área rural, sendo estranho, por isso, quando se trata de parcelamento de área do solo urbano, assim definidas pelo plano diretor ou aprovadas por lei municipal (art. $3^{\circ}$, da Lei 6.766/79).

Para Antunes (2012, p. 421), “a própria definição conceitual de APP indica que ela não se compatibiliza com áreas urbanas".

Parece-nos inequívoco que, havendo o reconhecimento protetivo das áreas de preservação permanente também às áreas urbanas, as funções e características dessas APPs devem ser analisadas como instrumento de política urbana, à luz dos institutos de direito urbanístico.

Nesse mesmo sentido, destaca Rúsvel Beltrame (2008, p. 202), Procurador do Município de Belo Horizonte, que "[...] a aplicação do Código Florestal no meio ambiente urbano se dá em contexto absolutamente diverso do meio ambiente rural.".

Pode-se afirmar, ainda, que:

[...] as áreas de preservação permanente em áreas urbanas não anulam o direito de construir do particular como regra geral. Nesses casos, surge verdadeira colisão entre dois princípios de estatura constitucional, o direito ao ambiente e o princípio da livre iniciativa associado ao direito fundamental de propriedade. A colisão de princípios deverá ser solucionada pelo método da proporcionalidade, conferindo-se peso às normas e fatos incidentes no caso concreto, buscando a conciliação dos dois valores em colisão. (BELTRAME, 2008, p. 207).

Nesse diapasão, apresenta-se plenamente possível, segundo o eminente Procurador do Município de Belo Horizonte, o consentimento do órgão ambiental competente para a intervenção em áreas de preservação ambiental localizadas em zonas urbanas. O consentimento estatal para a utilização da área, nesses casos, mostra-se como direito público subjetivo do particular.

Tratando-se de contextos diversos, os institutos relacionados à desapropriação de APP devem, por óbvio, levar em consideração as peculiaridades de sua localização. Assim, os critérios de cálculo do valor da indenização em áreas urbanas devem ser aplicados para toda a extensão do imóvel desapropriado, inclusive para as áreas de preservação permanente. Não há justificativa plausível para equiparar o valor de uma APP urbana ao de uma APP rural. 
A incoerência para a fixação do quantum indenizatório pela administração pública é flagrante. $\mathrm{O}$ ente público propõe o pagamento da indenização atrelando-o às características de um imóvel rural, mas, uma vez transferido o bem para o domínio público, a vegetação de APP é imediatamente suprimida para a realização de obras urbanas.

Constata-se que, não raras vezes, o município utiliza-se dos instrumentos previstos no direito administrativo urbanístico para promover a política urbana e suprimir a propriedade particular, mas se apega aos conceitos e institutos da política ambiental para calcular o valor da indenização expropriatória a menor.

Ora, considerando a localização urbana do imóvel (e de sua respectiva APP) e considerando que a APP tenha sido desapropriada para a realização de uma atividade/obra de política urbana, o cálculo do quantum indenizatório de toda a extensão do imóvel deve ser fixado a partir de parâmetros urbanos.

O cálculo da indenização das áreas de preservação permanente deve considerar, além da área objeto da desapropriação, outros fatores inerentes à propriedade e que interferem no quantum final, como sua aptidão agrícola ou urbana, a área ocupada, a dimensão e a localização do imóvel.

É exatamente em virtude da vocação agrícola dos imóveis rurais que o valor indenizatório para essas espécies de espaços territoriais ambientalmente protegidos, por vezes, mostra-se reduzido em relação à área remanescente, e com certeza deverá ser menor se comparado aos imóveis urbanos. Raras são as situações que justificam a supressão de vegetação de APP de imóvel rural previstas no artigo $8^{\circ}$ do CFlo/2012. A APP rural somente poderá ser utilizada com alguma finalidade econômica pelo proprietário do imóvel em ocasiões excepcionais. Convém ressaltar que a cobertura florística em APP também deve ser indenizada. A diminuta potencialidade econômica da APP rural justifica a utilização de critérios específicos para o cálculo de sua indenização.

As APPs localizadas nos limites da cidade, por sua vez, apresentam inegável aptidão urbana. A utilização dessas áreas para a implementação de políticas públicas urbanas pelos municípios justifica a aplicação do artigo $8^{\circ}$ da Lei 12.651/2012 e a consequente supressão da vegetação para obras de utilidade pública, com a finalidade de assegurar o bem-estar das populações humanas.

Diferentemente das APPs rurais, as urbanas apresentam enorme potencialidade de uso, sobretudo pelo poder público, o que também justifica a utilização de critérios indenizatórios específicos para os imóveis urbanos. Não é demais destacar que, por determinação constitucional, a indenização deve ser justa, o que significa dizer que para a realização do cálculo do quantum indenizatório devem ser observadas as características inerentes às APPs urbanas, além de serem considerados todos os demais dados e elementos inerentes à situação fática do imóvel.

\section{UTILIZAÇÃO ECONÔMICA DA ÁREA REMANESCENTE À DESAPROPRIAÇÃO}

A existência de Áreas de Preservação Permanente está intrinsecamente atrelada à sua função ambiental "de preservar os recursos hídricos, a paisagem, a estabilidade geológica e a biodiversidade, facilitar o fluxo gênico de fauna e flora e proteger o solo". (BRASIL, 2012). Com isso, uma área será considerada de preservação permanente caso se enquadre na previsão 
dos artigos $4^{\circ}$ e $6^{\circ}$ do $\mathrm{CFlo} / 2012$ (instituídas por lei ou por ato do poder público), além de exercer a sua função ambiental de preservar os bens naturais descritos na lei.

Observa Araújo (2008, p. 205), em sua obra intitulada "As áreas de preservação permanente e a questão urbana", que um dos principais objetivos do legislador ao determinar a preservação de APPs em zonas urbanas foi a proteção dos recursos hídricos. "Essa é a finalidade da extensão das áreas de preservação permanente às áreas urbanas", afirma a autora.

A descaracterização da área ambientalmente protegida a partir da implementação de determinadas intervenções humanas esvaziam o objetivo de proteção, embora possam ainda continuar a se enquadrar no conceito normativo.

Nos casos em que já houve intervenção em APP, por exemplo, para a implantação de obra de infraestrutura de transporte às margens de rio em área urbana, não há mais que se falar na permanência da referida limitação administrativa na área remanescente originária da APP por ausência de sua finalidade. Se a faixa de terreno mais próxima do curso d’água foi transformada em alça viária, a mais distante do corpo hídrico não mais exerce a função de proteção dos recursos naturais, tornando sem objeto a restrição à possibilidade de seu uso, em que pese ainda se inserir no literal enquadramento legal.

Como se vê, caso isso venha a acontecer, a faixa de terreno remanescente à intervenção humana perde também qualquer tipo de finalidade protetiva, o que justifica a sua utilização para o exercício de diversas atividades econômicas, dentro dos limites e coeficientes definidos pelas normas urbanísticas vigentes.

A possibilidade de intervenção em APP urbana e de exercício do direito de construir pelo particular reforça a exigência de que os critérios a serem utilizados para o cálculo do valor indenizatório, nesses casos, não poderão ser aqueles aplicáveis aos imóveis rurais, mas sim deverão ser aqueles vinculados ao aproveitamento dos imóveis urbanos.

Ademais, é relevante considerar também que a possibilidade de justificativa plausível até mesmo para a intervenção em APP urbana pelo particular torna plenamente possível a utilização econômica da área remanescente não desapropriada pelo poder público, caso tenha se perdido com a obra de infraestrutura qualquer tipo de função protetiva do meio ambiente.

\section{CONCLUSÕES}

Existem intervenções estatais na propriedade privada que importam criação de limitações restritivas ao direito de propriedade ou limitações supressivas. A desapropriação caracteriza-se como uma limitação supressiva, que impõe ao ente expropriante a necessidade de pagamento de uma indenização justa, prévia e em dinheiro.

A justa recomposição do patrimônio do expropriado constitui o tema de maior complexidade argumentativa relacionado ao instituto da desapropriação. $\mathrm{O}$ preço do bem se afigura como o único argumento de mérito que pode ser discutido pelo expropriado na ação de desapropriação judicial.

É pacífico na melhor doutrina e jurisprudência pátria que a indenização pela aquisição de área, pelo poder público, deverá considerar também as APPs existentes no imóvel, que deverão ser mensuradas e valoradas para a adequada e justa composição do quantum indenizatório. A proteção constitucional dispensada ao direito de propriedade pressupõe a plena indenizabilidade das coberturas vegetais que recobrem áreas dominiais privadas que integram imóvel urbano que se torna objeto de desapropriação. Não se afigura coerente com o sistema constitu- 
cional que o Estado se subtraia ao pagamento da indenização da APP simplesmente em razão da impossibilidade, pelo expropriado, de esgotamento das potencialidades econômicas dessa área. Como não se veda o aproveitamento econômico de áreas de preservação permanente, deve-se reconhecer a expressão econômica que lhes é ínsita, recompondo integralmente o patrimônio do particular.

Caso o ente expropriante não considere a APP no cômputo do preço, ao particular assegura-se o direito de recusar a proposta ofertada administrativamente para impugnar esse valor na subsequente fase judicial a ser instaurada pelo ente expropriante.

O CFlo/2012 prevê expressamente a possibilidade de intervenção ou supressão de vegetação em APP de imóveis urbanos, mediante autorização do órgão ambiental competente, nos casos de utilidade pública. Inúmeros serviços estatais demandam a supressão de vegetação em áreas de preservação permanente, tais como atividades de proteção sanitária, obras necessárias à defesa civil, além das obras de infraestrutura destinadas às concessões e aos serviços públicos de transporte, sistema viário, saneamento, gestão de resíduos e energia. Como se percebe, há nítido interesse do poder público na desapropriação de imóveis urbanos detentores de APPs.

Para que o valor da indenização na desapropriação se afigure justo, em respeito às determinações constitucionais, deve-se levar em consideração a função da APP em área urbana, a ser analisada de maneira sistêmica, nos termos dos instrumentos de direito urbanístico e das normas específicas que disciplinam as atividades urbanas, como o plano diretor e a lei de uso e ocupação do solo.

Não remanescem dúvidas de que o cálculo da indenização das áreas urbanas que constituem objeto de desapropriação deverá utilizar critérios distintos daqueles utilizados para o cálculo da indenização em áreas rurais, uma vez que se referem a objetos, pressupostos e usos diversos. Conforme demonstrado no presente trabalho, a adoção pela Administração Pública de critérios de cálculos específicos para os imóveis rurais na desapropriação de APP urbana afigura-se ilegal e, nesse ponto, se torna passível, inclusive, de impugnação judicial a ser oposta pelo expropriado como matéria de mérito em sede de contestação na própria ação de desapropriação.

\section{REFERÊNCIAS}

ANTUNES, Paulo de Bessa. Direito Ambiental. São Paulo: Atlas, 2012.

ARAÚJO, Giselle Marques de. Função ambiental da propriedade: uma proposta conceitual. Belo Horizonte: Revista Veredas do Direito, v. 14, n. 28, 2017, p. 251-276. Disponível em <http://www.domhelder.edu.br/revista/index.php/veredas/article/view/985>

ARAÚJO, Suely Mara Vaz Guimarães de. Trabalho da consultoria legislativa da Câmara dos Deputados, 2002. In: BELTRAME, Rúsvel. Ponderação constitucional nos direitos ambiental e urbanístico: solução para a colisão de interesses gerada pela aplicação do Código Florestal nas áreas urbanas. Revista da Procuradoria-Geral do Município de Belo Horizonte-RPGMBH, ano 1, n.1, jan/jun. 2008. Belo Horizonte: Fórum, 2008.

BELTRAME, Rúsvel. Ponderação constitucional nos direitos ambiental e urbanístico: solução para a colisão de interesses gerada pela aplicação do Código Florestal nas áreas urbanas. In: Revista da Procuradoria-Geral do Município de Belo Horizonte-RPGMBH, ano 1, n.1, jan/jun. 2008. Belo Horizonte: Fórum, 2008, p. 193 - 209. 
BRASIL. Superior Tribunal de Justiça. Agravo Regimental no Recurso Especial 1.317.806MG. Relator Ministro Humberto Martins. Data do julgamento: 6 nov. 2012-b.

BRASIL. Constituição (1988). Constituição da República Federativa do Brasil. Brasília, DF: Senado Federal: Centro Gráfico, 1988.

BRASIL. Lei n. 12.651, de 25 de mai. de 2012. Dispõe sobre a proteção da vegetação nativa, Brasília, DF, mai 2012.

BRASIL. Superior Tribunal de Justiça. Recurso Especial 95299-SP. Relator Ministro José de Jesus Filho. Data do julgamento: 20 fev.1997.

BRASIL. Supremo Tribunal Federal. Recurso Extraordinário 134297-SP. Relator Ministro Celso de Mello. Data do julgamento: 13 jun.1995.

BRASIL. Tribunal Regional Federal da 4 ${ }^{\text {a }}$ Região. EINF 200472000100900. Relatora: Maria Lúcia Luiz Leiria, Data do julgamento: 8 set. 2008.

CARVAlHO FILHO, José dos Santos. Manual de Direito Administrativo. São Paulo: Atlas, 2013.

DI PIETRO, Maria Sylvia Zanella. Direito administrativo. 13. ed. São Paulo: Atlas, 2001.

MARINELA, Fernanda. Direito administrativo. 4. ed. Niterói: Impetus, 2010.

MATIAS, João Luis Nogueira; MENDES, Davi Guimarães. A exclusão de sócio incapaz na sociedade limitada: análise à luz do princípio da função social da empresa. Revista Jurídica da FA7: periódico científico do Programa de Pós-Graduação em Direito da Faculdade 7 de Setembro / FA7, v.13, n.2 (jul./dez. 2016). Fortaleza: FA7, 2016.

PARANÁ. Tribunal de Justiça. Apelação Cível 143.834-2. Relator Desembargador Munir Karam. Data do Julgamento: 25 mai. 2004.

SANTA CATARINA. Tribunal de Justiça. ACMS 2003.003060-3, de Joaçaba. Relator Desembargador Luiz Cézar Medeiros.

THOMÉ, Romeu. Manual de Direito Ambiental. 8. ed. Salvador: Juspodivm, 2018.

Recebido em: 30 dez. 2017.

Aceito em: 29 abr. 2018. 